\title{
Peningkatan Kadar Hb Pada Kejadian Anemia dengan Pemberian Sirup Kalakai
}

\author{
Sofia Mawaddah \\ Poltekkes Kemenkes Palangka Raya, \\ Email:sofizline@gmail.com, \\ Tlp:+6282148530101
}

Naskah Diterima : 02 Oktober 2018 Disetujui : 10 Desember 2018

Publikasi : Januari 2019

\begin{abstract}
ABSTRAK
Latar Belakang : Sebagian besar remaja puteri menderita defisiensi $\mathrm{Fe}$ dan anemia Fe karena meningkatnya kebutuhan Fe selama masa pertumbuhan. Akibat jangka panjang anemia defisiensi besi pada remaja puteri adalah apabila remaja puteri nantinya hamil, maka ia tidak akan mampu memenuhi zat-zat gizi bagi dirinya dan juga janin dalam kandungannya serta pada masa kehamilannya. Sebagian besar masyarakat, Kalakai hanya dimanfaatkan sebagai sayuran yang tumbuh di sekitar tempat tinggal mereka untuk melengkapi konsumsi pangan diolah dengan cara direbus, bening, oseng, dan lain-lain. Salah satu cara pemanfaatan Kalakai adalah dengan mengolah Kalakai menjadi sirup.

Tujuan : Penelitian ini bertujuan untuk mengetahui peningkatan kadar $\mathrm{Hb}$ pada kejadian anemia dengan kejadian anemia dengan pemberian sirup kalakai.

Metode : penelitian ini menggunakan Quasy eksperiment. sampel adalah mahasiswa pada Prodi DIV Kebidanan Poltekkes Palangka Raya sebanyak 10 orang. Analisis data yang digunakan pada penelitian ini adalah Paired T Test.

Hasil : uji statistik dengan uji t sebesar -6.859 dengan probabilitas sebesar 0.000. Hal ini dapat diketahui bahwa probabilitas < alpha $(2.5 \%)$, sehingga H0 ditolak. Oleh karena itu, disimpulkan bahwa kadar $\mathrm{Hb}$ mahasiswa yang mengalami anemia sesudah pemberian sirup kalakai lebih tinggi dibandingkan kadar $\mathrm{Hb}$ sebelum pemberian sirup kalakai. Sebagai rekomendasi dari hasil penelitian adalah sirup kalakai bisa menjadi salah satu solusi dalam meningkatkan kadar $\mathrm{Hb}$.
\end{abstract}

\section{Kata Kunci : Sirup kalakai, Kadar Hb, Remaja putri}

\section{PENDAHULUAN}

Remaja merupakan tahap dimana seseorang mengalami sebuah masa transisi menuju dewasa. Remaja adalah tahap umur yang datang setelah masa kanakkanak berakhir, ditandai oleh pertumbuhan fisik yang cepat. Remaja dalam masyarakat dikenal dengan berbagai istilah yang menunjukkan kelompok umur yang tidak termasuk kanak-kanak tetapi bukan pula dewasa. Pada umumnya, anemia lebih sering terjadi pada wanita dan remaja putri dibandingkan dengan pria. Yang sangatdisayangkan adalah kebanyakan penderita tidak tahu atau tidak menyadarinya. Bahkan ketika tahu pun masih menganggap anemia sebagai masalah sepele. ${ }^{(\mathbf{1})}$

Anemia adalah suatu kondisi medis dimana kadar hemoglobin kurang dari normal. Kadar $\mathrm{Hb}$ normal pada remaja putri adalah >12 g /dl. Remaja putri dikatakan anemia jika kadar $\mathrm{Hb}<12$ gr/dl. (2) Anemia merupakan masalah gizi di dunia, terutama di negara berkembang termasuk Indonesia. Angka anemia gizi besi di Indonesia sebanyak 72,3\%. 
Kekurangan besi pada remaja mengakibatkan pucat, lemah, letih, pusing, dan menurunnya konsentrasi belajar.

Angka prevalensi anemia di Indonesia, yaitu pada remaja wanita sebesar 26,50\%, pada wanita usia subur sebesar 26,9\%, pada ibu hamil sebesar $40,1 \%$ dan pada balita sebesar $47,0 \%{ }^{(3)}$ Menurut WHO, angka kejadian anemia pada remaja putri di Negara- negara berkembang sekitar $53,7 \%$ dari semua remaja putri, anemia sering menyerang remaja putri disebabkan karena keadaan stress, haid, atau terlambat makanan. ${ }^{(4)}$

Sebagian besar remaja puteri menderita defisiensi $\mathrm{Fe}$ dan anemia $\mathrm{Fe}$ karena meningkatnya kebutuhan Fe selama masa pertumbuhan. Remaja puteri semakin banyak kehilangan $\mathrm{Fe}$ akibat menstruasi, menyusui, dan hamil (5). Akibat jangka panjang anemia defisiensi besi pada remaja puteri adalah apabila remaja puteri nantinya hamil, maka ia tidak akan mampu memenuhi zat-zat gizi bagi dirinya dan juga janin dalam kandungannya serta pada masa kehamilannya. Anemia ini dapat meningkatkan frekuensi komplikasi, rIsiko kematian maternal, angka prematuritas, BBLR, dan angka kematian perinatal (6)

Selain karena kurangnya asupan dari zat besi, anemia juga bisa terjadi karena pengaruh kemampuan penyerapan zat besi itu sendiri. Faktor penyerapan zat besi juga menjadi perhatian penting. AKG besi untuk remaja dan dewasa muda perempuan 19-26 mg setiap hari. Salah satu bahan makanan yang mengandung zat besi dan vitamin $\mathrm{C}$ tinggi adalah Kalakai. Kalakai merupakan salah satu dari beberapa tanaman tradisional khas Kalimantan Tengah yang memiliki sebaran yang sangat banyak dan umumnya belum banyak dimanfaatkan.

Selama ini berkembang di masyarakat tentang peran fungsional Kalakai terhadap anemia karena $\mathrm{Fe}$ yang dikandungnya. Berdasarkan studi empirik, Kalakai dipergunakan oleh masyarakat suku Dayak Kenyah untuk mengobati anemia, pereda demam, mengobati sakit kulit dan sebagai obat diare. Meskipun demikian bukti empirik tersebut belum pernah dibuktikan secara ilmiah. Kandungan metabolit sekunder tanaman Kalakai dari hasil pengukuran sampel daun dan batang yaitu untuk kandungan $\mathrm{Fe}$ tertinggi pada bagian daun sebesar 291,32 $\mathrm{mg} / 100 \mathrm{~g}$ bila dibandingkan dengan bayam yang memiliki kandungan $\mathrm{Fe}$ pada daun yaitu sebesar 3,9 mg/100 $\mathrm{g}$ (7)

Sebagian besar oleh masyarakat, Kalakai hanya dimanfaatkan sebagai sayuran yang tumbuh di sekitar tempat tinggal mereka untuk melengkapi konsumsi pangan diolah dengan cara direbus, bening, oseng, dan lain-lain. Dengan demikian perlu dicari alternatif lain cara pemanfaatan tumbuhan Kalakai ini, selain itu juga untuk mempertahankan mutu dan memperpanjang masa simpan Kalakai. Salah satu cara pemanfaatan Kalakai adalah dengan mengolah Kalakai menjadi sirup. Kelebihannya adalah mudah dilarutkan dalam air, praktis dalam penyajian dan memiliki daya simpan yang relatif lama, mempermudah mengkonsumsinya dan tidak membutuhkan waktu yang lama untuk menyajikannya. (8)

Produk minuman sirup banyak disukai dan dapat dikonsumsi oleh semua kalangan mengingat iklim tropis kita yang memungkinkan orang lebih memilih 
minuman segar. Menurut SNI 3544:2013, sirup adalah produk minuman yang dibuat dari campuran air dan gula dengan kandungan larutan gula minimal $65 \%$ dengan atau tanpa bahan pangan lain dan atau bahan tambahan pangan yang diijinkan sesuai dengan ketentuan yang berlaku. Selama ini sirup yang beredar di pasaran memiliki komposisi berupa gula, asam sitrat, zat pewarna, zat penstabil, bahan pengawet, pemanis buatan serta aroma buah-buahan. Sedangkan kandungan gizinya masih sangat sedikit (9)

Kalakai sendiri merupakan tanaman yang kaya akan zat gizi terutama $\mathrm{Fe}$, selama ini berkembang di masyarakat tentang peran fungsional Kalakai terhadap anemia karena $\mathrm{Fe}$ yang dikandungnya. Diharapkan dengan adanya sirup dari Kalakai ini dapat menjadi alternatif bagi masyarakat khususnya remaja putri untuk mengkonsumsi sumber Fe. Sirup Kalakai $100 \%$ menghasilkan rata-rata kandungan Fe sebesar 3,221 mg/100ml, sedangkan rata-rata kandungan Vitamin $\mathrm{C}$ menghasilkan 78,120 mg/100ml. Dari hasil tersebut dapat disimpulkan bahwa sirup Kalakai dapat membantu untuk memenuhi kecukupan $\mathrm{Fe}$ remaja putri, sedangkan kandungan vitamin $\mathrm{C}$ pada sirup Kalakai ini juga penting untuk membantu reduksi $\mathrm{Fe}^{3+}$ menjadi $\mathrm{Fe}^{2+}$ sehingga zat besi lebih mudah diserap oleh tubuh. Berdasarkan uraian di atas penulis tertarik untuk meneliti Pengaruh pemberian sirup kalakai terhadap kadar $\mathrm{Hb}$ mahasiswa yang mengalami anemia.

METODE

Penelitian ini menggunakan desain Quasy Experiment (One-Group Pre-Post Test Design). Pengambilan sampel menggunakan purposive sampling. Penelitian ini menggunakan data sekunder yaitu hasil $\mathrm{Hb}$ mahasiswi prodi DIV Kebidanan angkatan I. Populasi penelitian ini adalah seluruh mahasiswi prodi DIV kebidanan angkatan I Poltekkes Palangka Raya. Sampel pada penelitian ini adalah mahasiswa prodi DIV kebidanan angkatan I yang memenuhi kriteria inklusi dan kriteria eksklusi.

Teknik pengumpulan data menggunakan data primer melalui wawancara dengan Mahasiswa Prodi DIV Kebidanan Poltekkes Palangka Raya dan hasil pemeriksaan kadar $\mathrm{Hb}$ dengan persetujuan dengan responden Setelah mendapat informed consent, selanjutnya dilakukan pre-intervensi pemeriksaan kadar hemoglobin (Hb). Alat yang digunakan peneliti untuk pengumpulan data primer yaitu alat untuk Hemoglobin Testing System Quick Check.

Analisis data yang digunakan pada penelitian ini adalah Paired $\mathrm{T}$ Test untuk menguji perbedaan Kadar $\mathrm{Hb}$ Mahasiswa yang Mengalami Anemia Sebelum dan Sesudah Pemberian Sirup Kalakai dengan tingkat kemaknaan $\alpha<0,025$.

HASIL

\section{Tabel 1. Identitas Responden Berdasarkan Berat Badan}

\begin{tabular}{lcccc}
\hline Berat Badan & Frekuensi & Persentase & Rata-Rata & Simpangan Baku \\
\hline $45-47 \mathrm{Kg}$ & 2 & $20.0 \%$ & & \\
$48-50 \mathrm{Kg}$ & 7 & $70.0 \%$ & 48.50 & 1.51 \\
$>50 \mathrm{Kg}$ & 1 & $10.0 \%$ & & \\
Total & 10 & $100 \%$ & & \\
\hline
\end{tabular}


Berdasarkan tabel 1 diketahui bahwa paling banyak mahasiswi memiliki berat badan 48 - $50 \mathrm{~kg}$ dengan rata-rata berat badan mahasiswi yang berpartisipasi dalam penelitian ini adalah $48.5 \mathrm{~kg}$ dengan simpangan baku sebesar 1.51.
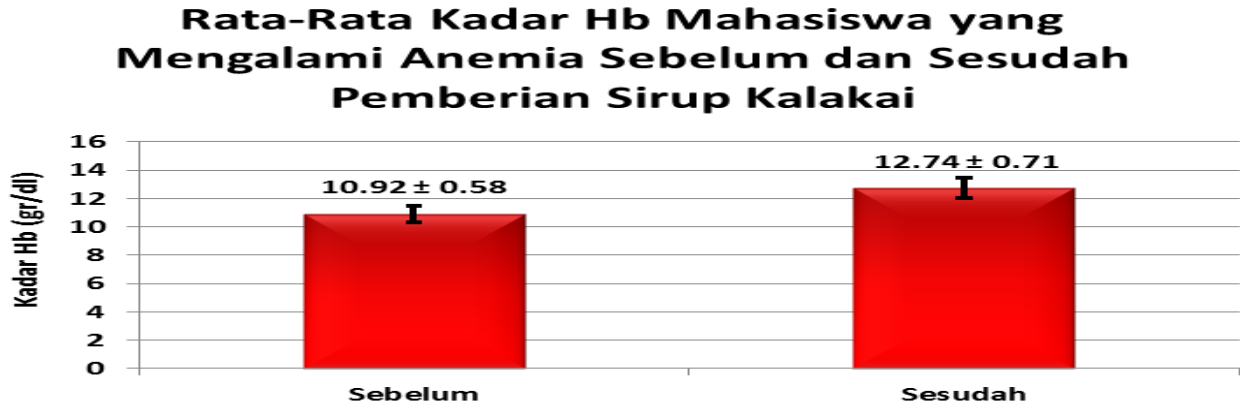

Gambar diatas menginformasikan kadar $\mathrm{Hb}$ mahasiswa yang mengalami anemia sesudah pemberian sirup kalakai memiliki rata-rata yang lebih tinggi dibandingkan kadar $\mathrm{Hb}$ sebelum pemberian sirup kalakai.

\section{Pengujian Kenormalan Data}

Pengujian kenormalan data kadar $\mathrm{Hb}$ mahasiswa yang mengalami anemia sebelum dan sesudah pemberian sirup kalakai bertujuan untuk mengetahui normal tidaknya data tersebut.

Pengujian kenormalan data dilakukan menggunakan KolmogorovSmirnov, dengan kriteria apabila nilai probabilitas > level of significance (alpha $=5 \%$ ) maka data dinyatakan normal. Hasil pengujian normalitas data kadar $\mathrm{Hb}$ mahasiswa yang mengalami anemia sebelum dan sesudah pemberian sirup kalakai dapat dilihat melalui tabel berikut :

\begin{tabular}{|l|c|}
\hline Kolmogorov- Smirnov & 0.140 \\
\hline Probabilitas & 0.200 \\
\hline
\end{tabular}

Berdasarkan tabel di atas dapat diketahui bahwa pengujian normalitas kadar $\mathrm{Hb}$ mahasiswa yang mengalami anemia sebelum dan sesudah pemberian sirup kalakai menghasilkan probabilitas > alpha (5\%), sehingga data tersebut dinyatakan normal.

Tabel 2. Perbedaan Kadar Hb Mahasiswa Yang Mengalami Anemia Sebelum Dan Sesudah Pemberian Sirup Kalakai

\begin{tabular}{lcccc}
\hline Kadar Hb & Rata-Rata & T Statistics & $\begin{array}{c}\text { Probabilitas } \\
(\mathbf{2} \text { arah })\end{array}$ & $\begin{array}{c}\text { Probabilitas } \\
(\mathbf{1} \text { arah })\end{array}$ \\
\hline $\begin{array}{l}\text { Sebelum Pemberian } \\
\text { Sirup Kalakai }\end{array}$ & 10.920 & -6.859 & $\begin{array}{c}0.000 \\
(\text { Alpha 5\%) }\end{array}$ & $\begin{array}{c}0.000 \\
(\text { Alpha 2.5\%) }\end{array}$ \\
$\begin{array}{l}\text { Sesudah Pemberian } \\
\text { Sirup Kalakai }\end{array}$ & 12.740 & & & \\
\hline
\end{tabular}

Berdasarkan tabel 2 diketahui bahwa pengujian perbedaan kadar $\mathrm{Hb}$ mahasiswa yang mengalami anemia sebelum dan sesudah pemberian sirup kalakai menghasilkan statistik uji t sebesar -6.859 dengan probabilitas sebesar 0.000 . Hal ini 
dapat diketahui bahwa probabilitas < alpha (2.5\%), sehingga H0 ditolak. Oleh karena itu, dapat dinyatakan bahwa kadar $\mathrm{Hb}$ mahasiswa yang mengalami anemia sesudah pemberian sirup kalakai lebih tinggi dibandingkan kadar $\mathrm{Hb}$ mahasiswa yang mengalami anemia sebelum pemberian sirup kalakai.

\section{PEMBAHASAN}

Hasil penelitian menunjukkan bahwa nilai rata-rata kadar $\mathrm{Hb}$ mahasiswa yang mengalami anemia sesudah pemebrian sirup kalakai lebih tinggi dibandingkan dengan nilai rata-rata kadar $\mathrm{Hb}$ mahasiswa yang mengalami anemia sebelum pemberian sirup kalakai. Zat besi adalah unsur vital untuk pembentukan hemoglobin, juga merupakan komponen penting pada system enzim pernafasan. Fungsi zat besi adalah membentuk sel darah merah, sehingga apabila produksi sel daragh merah dalam tubuh tidak cukup maka kadar hemoglobin akan normal.

Kalakai merupakan salah satu dari beberapa sayuran tradisional khas Kalimantan Tengah. Kalakai biasanya dikonsumsi dikonsumsi dalam bentuk sayur. Pada peneitian ini kalakai diolah dalam bentuk sirup agar bisa dikonsumsi setiap saat, tahan lama dan lebih praktis.

Menurut BPOM RI tahun 2011, suatu pangan olahan dalam bentuk cair dikatakan tinggi kandungan $\mathrm{Fe}$ dan vitamin $\mathrm{C}$ apabila mempunyai kadar sedikitnya $15 \%$ dari Acuan Label Gizi (ALG) per $100 \mathrm{ml}$. sementara BPOM RI tahun 2007 tentang Acuan Label Gizi Produk Pangan, nilai acuan kandungan $\mathrm{Fe}$ pada produk pangan sebesar $26 \mathrm{mg}$ sedangkan kandungan vitamin $\mathrm{C}$ sebesar 90 mg. Berarti 15\% kandungan $\mathrm{Fe}$ dari
ALG adalah sebesar 3,9 mg, sedangkan kandungan vitamin $\mathrm{C}$ sebesar 13,5 mg. Berdasarkan penelitian Ratna tahun 2015 Sirup Kalakai $100 \%$ dari 100 gr kalakai menghasilkan rata-rata kandungan $\mathrm{Fe}$ sebesar 3,221 mg/100ml. Pada penelitian ini, berdasarkan hasil uji Laboratorium di Laboratorium Farmasi Universitas Lambung Mangkurat, Sirup Kalakai 100\% dari 100 gr kalakai menghasilkan rata-rata kandungan Fe sebesar 47,4 mg/100ml. (11) WHO, tahun 2010.Remaja putri lebih rentan anemia dibandingkan dengan remaja laki-laki. Itu disebabkan kebutuhan zat besi pada remaja putri adalah 3 kali lebih besar dari laki-laki. Remaja putri setiap bulan mengalami menstruasi yang secara otomatis mengeluarkan darah. Itu sebabnya remaja putri memerlukan zat besi untuk mengembalikan kondisi tubuhnya ke keadaan semula. Anemia sering menyerang remaja putri disebabkan karena keadaan stress, haid, atau terlambat makan.

Pada penelitian ini sampel yang digunakan adalah mahasiswi yang mengalami anemia. Hasil penelitian menunjukkan bahwa dari hasil uji statistik ditinjau dari rata-rata kadar $\mathrm{Hb}$ mahasiswa yang mengalami anemia sebelum pemberian sirup kalakai sebesar 10.920, sedangkan rata-rata kadar $\mathrm{Hb}$ mahasiswa yang mengalami anemia sesudah pemberian sirup kalakai sebesar 12.740. Hal ini menunjukkan bahwa nilai rata-rata kadar $\mathrm{Hb}$ mahasiswa yang mengalami anemia sesudah pemberian sirup kalakai lebih tinggi dibandingkan dengan nilai rata-rata kadar $\mathrm{Hb}$ mahasiswa yang mengalami anemia sebelum pemberian sirup kalakai.

Penelitian ini membuktikan dengan mengkonsumsi sirup kalakai dapt menaikkan kadar $\mathrm{Hb}$, karena di dalam sirup kalakai terdapat kandungan zat besi 
dan vit C. Zat besi adalah unsur vital untuk pembentukan hemoglobin, fungsi dari zat besi adalah membentuk sel darah merah, sehingga apabila produksi sel darah merah dalam tubuh cukup maka kadar hemoglobin akan normal. ${ }^{(10)}$

Kalakai memiliki beberapa manfaat yaitu,kalakai yang berwarna merah sangat potensial untuk mengatasi anemia (kekurangan zat besi). Menurut Irawan et al, dari analisis gizi diketahui bahwa kalakai merah mengandung Fe yang tinggi (41,53 ppm), $\mathrm{Cu}$ (4,52 ppm), vitamin $\mathrm{C}$ $(15,41 \mathrm{mg} / 100 \mathrm{gr})$, protein $(2,36 \%)$, beta karoten $(66,99 \mathrm{ppm})$ dan asam folat $(11,30$ ppm).

Studi Potensi Kalakai (Stenochlaena Palustris (Burm.F) Bedd), sebagai pangan fungsional pada penelitian yang meliputi analisa proksimat, uji mineral ( $\mathrm{Fe}$ dan $\mathrm{Ca}$ ), uji vitamin $\mathrm{C}$ dan vitamin $\mathrm{A}$ dan uji fitokimia (flavonoid,alkoid dan steroid). Hasil pengukuran sampel daun batang yaitu untuk kadar air 8,56\% dan 7,28\%, kadar abu 10,37\% dan 9,19\%, kadar serat kasar 1,93\% dan 3,19\%, kadar protein $11,48 \%$ dan $1,89 \%$, kadar lemak 2,63\% dan $1,37 \%$. Hasil analisis mineral Ca lebih tinggi di daun dibandingkan batang yaitu
$182,07 \mathrm{mg}$ per 100gr, demikian pula dengan Fe tertinggi 291,32 mg per 100gr. Hasil analisis vitamin $\mathrm{C}$ tertinggi terdapat di batang $264 \mathrm{mg}$ per $10 \mathrm{~g}$ dan vitamin A tertinggi terdapat di daun 26976,29 ppm. Hasil analisa fitokimia flavonoid, alkaloid dan steroid tertinggi terdapat pada batang sebesar 3,010\%, 3,817\% dan 2,583\%. Senyawa bioaktif yang paling dominan adalah alkaoid. ${ }^{(12)}$

\section{KESIMPULAN}

Rata-rata kadar $\mathrm{Hb}$ mahasiswa yang mengalami anemia sebelum dan sesudah pemberian sirup kalakai terjadi peningkatan hasil uji statistik disimpulkan bahwa kadar $\mathrm{Hb}$ mahasiswa yang mengalami anemia sesudah pemberian sirup kalakai lebih tinggi dibandingkan kadar $\mathrm{Hb}$ mahasiswa yang mengalami anemia sebelum pemberian sirup kalakai.

\section{SARAN}

Kiranya dapat dipertimbangkan Sirup kalakai sebagai alternatif dalam meningkatkan kadar HB

\section{UCAPAN TERIMA KASIH}

Peneliti sangat berterima kasih kepada mahasiswa kebidanan angkatan I yang bersedia menjadi responden pada penelitian ini.

\section{DAFTAR PUSTAKA}

1. Yusuf S. Psikologi Perkembangan Anak \& Remaja. Bandung: PT Remaja Rosdakarya; 2004.

2. Proverawati A. Anemia dan Anemia Kehamilan. Yogyakarta: Nuha Medika; 2011.

3. Burner. Faktor-Faktor yang Berhubungan dengan Kejadian Anemia Remaja Putri. Jakarta: EGC; 2012.

4. World Health Organization. Haemoglobin concentrations for the diagnosis of anaemia and assessment of severity. World Health Organization. 2011. p. 6.

5. Fatmah. Gizi Pada Remaja Putri. Yogyakarta: Nuha Medika; 2010.

6. Sitohang, Febriany N. Klasifikasi Anemia. Yogyakarta: Nuha Medika; 2012.

7. Riskayanti. Tumbuhan Lahan Basah. Jakarta: Prenanda Media Group; 2014.

8. Hadiwijaya H. Pengaruh Perbedaan Penambahan Gula Terhadap Karakteristik Sirup Buah Naga Merah (Hylocereus polyrhizus) [Internet]. Repository Universitas Andalas. 2014. p. 1-9. Available from: http://repository.unand.ac.id/20528/

9. Renata SR. Evaluation of Decentralization Outcomes in Indonesia: Analysis of Health and Education Sectors [Internet]. Georgia State University; 2009. Available from: 
https://scholarworks.gsu.edu/econ_diss/58/

10. Arisman. Gizi Dalam Daur Kehidupan. Jakarta: EGC; 2007.

11. BPOM RI. Peraturan Kepala Badan Pengawas Obat dan Makanan Republik Indonesia Nomor Hk. 03.1. 23.06. 11.5629 Tahun 2011 tentang Persyaratan Teknis Cara Pembuatan Obat Tradisional Yang Baik. Jakarta: Badan Pengawas Obat dan Makanan Republik Indonesia; 2011.

12. Maharani DM, Haidah SN, Haiyinah. Studi Potensi Kalakai (Stenochlaena palustris (BURM.F) BEDD), Sebagai Pangan Fungsional. Pimnas 2006 [Internet]. 2006; Available from: http://student-research.umm.ac.id/ index. php/ pimnas/article/view/255 